\title{
Wholesale Price Index as a measure of Inflation with special reference to basic commodities
}

\section{* Dr. Preeti Sharma}

Effulgence

Vol. 14 No. 1

January - June, 2016

Rukmini Devi Institute of Advanced Studies

E-mail : effulgence@rdias.ac.in, Website : www.rdias.ac.in

http://effulgence.rdias.ac.in/user/default.aspx

https://dx.doi.org/10.33601/effulgence.rdias/v14/i1/2016/26-31

\begin{abstract}
In current scenario inflation has become a very unpopular happening in an economy. Opinion survey conducted in India, the U.S.A. and other countries of the world reveal that inflation is the most important concern of the people as it adversely affects the standard of living of the people. Inflation may be termed as persistently rising prices in an economy. A bigh rate of inflation is responsible for making the life of the poor very miserable therefore it is described as anti-poor. So the current study focuses on the rate of inflation in India. The paper compares the rate of inflation of basic commodities (Wheat, MILK, LPG, Petrol, and Electricity in domestic consumption) to WPI index. The paper emphasizes that the inflation shown by WPI index talks about 636 commodities which may not present the real picture of inflation in case of basic commodities. Since the high rate of inflation (on basic commodities) may be traded off by the low rate of inflation on other commodities. If the rate of inflation is anticipated correctly, the people take steps to make suitable adjustments to avoid the adverse effects of inflation.
\end{abstract}

Key Words: Wholesale Price Index, Inflation, Consumer Price Index, Economic growth.

\section{INTRODUCTION}

I nflation may be termed as persistent rise in the general price level rather than a once-for-all rise in it. Inflation rate of a country is the rate at which price of goods and services increase in its economy. Inflation is usually measured on the basis of certain indices. Broadly, there are two categories of indices for measuring inflation i.e. Wholesale Prices and Consumer Prices. Inflation rates in India are usually quoted as changes in the Wholesale Price Index, for all commodities. Many developing countries use changes in the Consumer Price Index (CPI) as their central measure of inflation. The Reserve Bank of India (RBI) Governor, Raghuram Rajan, declared a new Consumer Price Index (CPI) (combined) as the key measure of inflation in April 2014. Earlier, RBI had given more weightage to Wholesale Price Index (WPI) than CPI as the key measure of inflation for all policy purposes.

\section{Wholesale Price Index}

WPI is published by the Office of Economic Adviser, Ministry of Commerce and Industry. It is widely used by Government, banks, industry and business circles. All the Important monetary and fiscal policy decisions and changes are linked to WPI movements.

The WPI consists of a basket of 676 commodities (revised from 435 with base year 1993-94) and their price changes are used to calculate the value of the index. The current series of Wholesale Price Index has 2004-05 as the base year and the base value of the index is 100. The percentage change in the value of the index over a specified period reflects the inflation rate.

\section{Calculation of WPI value}

Let us calculate WPI for the year 2015 for a particular commodity, say wheat taking 2005 as base year. Assume 
that the price for a kilogram of wheat in $2005=$ Rs. 14 and in $2015=$ Rs. 25. Therefore, the WPI for the year 2015 is:-

(Price of wheat in 2005 - Price of wheat in 2015) / (Price of wheat in 2005) *100 i.e. $(25-14) /(14) * 100==$ 64.28

Since WPI for the base year is assumed as 100, WPI for 2010 will become $100+64.28=164.28$. In this way individual WPI values for the remaining 675 commodities are calculated and then the weighted average of individual WPI figures are found out to arrive at the overall Wholesale Price Index. Commodities are given weightage in accordance with their influence in the economy.

\section{Calculation of Inflation}

If we have WPI values for two time zones, say beginning and end of the year, the inflation rate for the year will be :-

(WPI at end of year - WPI at beginning of year) / (WPI at beginning of year) $* 100$

For example, WPI on Jan 12014 is 142 and that on Jan 1 2015 is 153.75 then inflation for the year 2015 would be :-

$(153.75-142) /(142) * 100=8.27 \%$. Thus we say that inflation for the year 2015 is $8.27 \%$.

\section{Need for the study}

In any country, no one price index will measure the impact of price changes on the entire population. The former RBI Governor D. Subbarao as quoted:- "In India, we have one Wholesale Price Index and three Consumer Price Indices. There are ongoing efforts at the technical level to reduce the number of consumer price indices, and I believe the technical issues are not insurmountable. But that still will not give us a single representative inflation rate for an emerging market economy with market imperfections, diverse geography and 1.2 billion people."

The current study explains the limitations of WPI in estimating the rate of inflation.

\section{OBJECTIVES OF THE STUDY}

- To study the effectiveness of WPI for measuring inflation.

- To study the changes in price of five basic commodities and compare them with WPI changes.

\section{RESEARCH METHODOLOGY}

Source of data collection

The current study on based on secondary data. The data has been collected from the official of office of economic advisor. The WPI index and the price index of five basic commodities (Wheat, Petrol, MILK, LPG and domestic electricity) have been taken.

\section{Period of study}

A period of 10 years i.e. 2005 to 2015 has been taken for the study.

\section{Research Hypotheses}

For the current study the researcher has assumed that WPI is a correct indicator of inflation if the average rate of inflation is a representative of inflation of basic commodities (i.e. there is no differences between two averages)

Ho: There is no significant difference between average inflation by WPI and average inflation of any basic commodity.

\section{Research tool used}

For the current study z statistics has been calculated at $5 \%$ level of significance.

\section{ANALYSIS AND INTERPRETATION}

It can be observed from the graph below that the price indices for five commodities are close to all commodities from the year 2005-06 to 2008-09. After this period the distance of price index of individual commodities from WPI is increasing. This may be because the base year is 2004-05 and as we are moving away from this period the distance is increasing. This increasing distance shows that the composite inflation rate is not able to predict the inflation of individual commodity roughly. 
Chart showing price indices for commodities

Chart: 1

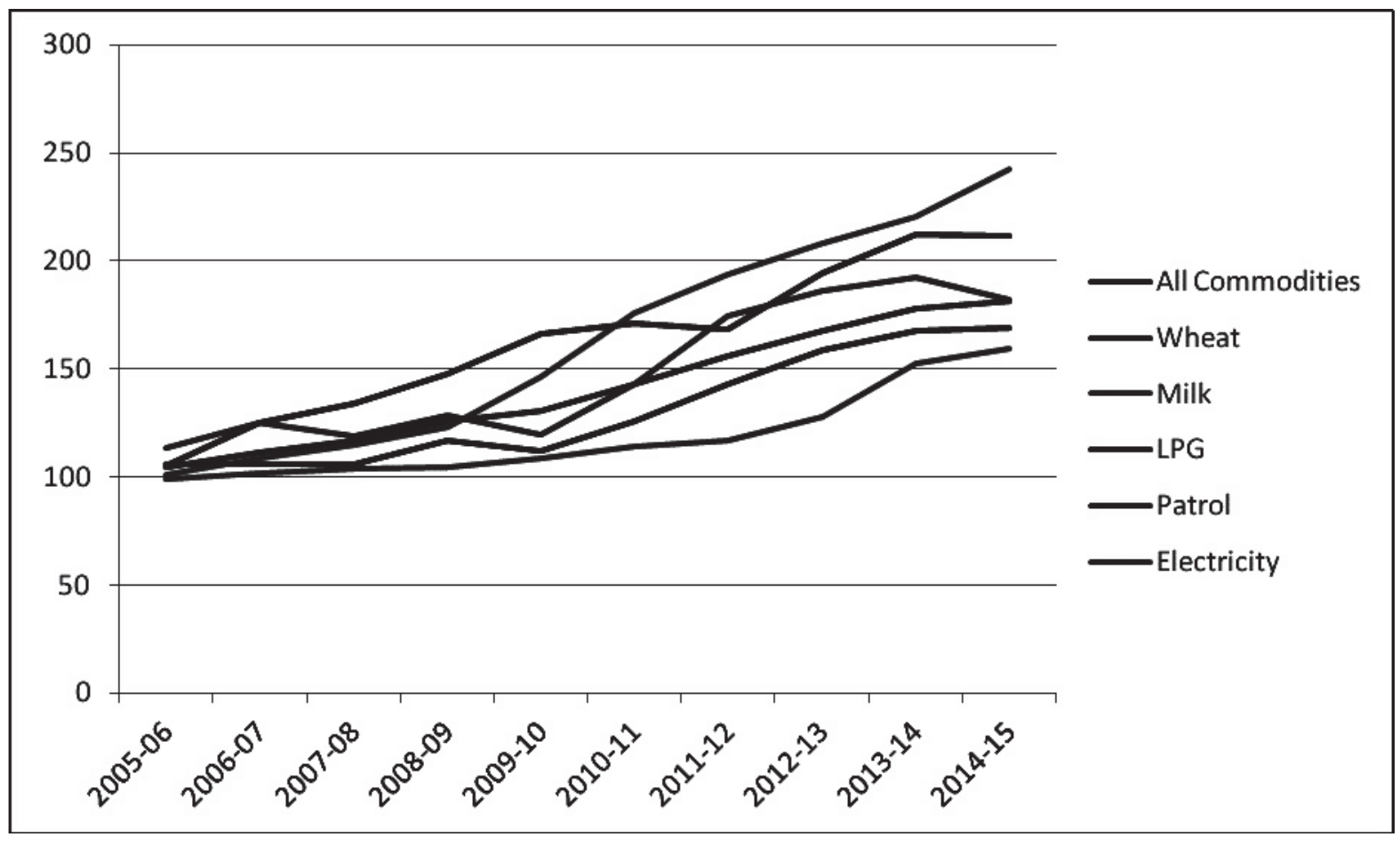

Table 1 shows the average price index of different commodities individually and of all commodities with their standard deviations.

Table: 1

\begin{tabular}{|l|c|c|c|c|}
\hline COMMODITIES & $\mathrm{N}$ & Mean & Std. Deviation & Std. Error Mean \\
\hline All commodities & 120 & 141.5183 & 26.77876 & 2.44456 \\
\hline Wheat & 120 & 163.6483 & 35.07864 & 3.20223 \\
\hline Patrol & 120 & 147.3763 & 33.63639 & 3.07057 \\
\hline Electricity & 120 & 118.9658 & 20.35575 & 1.85822 \\
\hline Milk & 120 & 163.5417 & 49.25622 & 4.49646 \\
\hline LPG & 120 & 131.2008 & 25.69728 & 2.34583 \\
\hline
\end{tabular}




\section{Testing of Hypothesis}

$\mathrm{Ho}_{\mathbf{a}}$ : There is no significant difference between average WPI and average price index of wheat.

\begin{tabular}{|c|c|c|c|c|c|c|c|c|c|c|}
\hline \multicolumn{11}{|c|}{ Independent Samples Test } \\
\hline & & \multicolumn{2}{|c|}{$\begin{array}{c}\text { Levene's Test for } \\
\text { Equality of Variances }\end{array}$} & \multicolumn{7}{|c|}{ t-test for Equality of Means } \\
\hline & & $\bar{F}$ & Sig. & $t$ & $\mathrm{df}$ & $\begin{array}{l}\text { Sig. }(2- \\
\text { tailed) }\end{array}$ & $\begin{array}{c}\text { Mean } \\
\text { Difference }\end{array}$ & \begin{tabular}{|l|} 
Std. Error \\
Difference
\end{tabular} & \multicolumn{2}{|c|}{$\begin{array}{l}\text { 95\% Confidence } \\
\text { Interval of the } \\
\text { Difference }\end{array}$} \\
\hline \multirow{2}{*}{ PI_INDEX } & $\begin{array}{l}\text { Equal variances } \\
\text { assumed }\end{array}$ & 6.578 & .011 & -5.493 & 238 & .000 & -22.13000 & 4.02866 & -30.06639 & -14.19361 \\
\hline & $\begin{array}{l}\text { Equal variances } \\
\text { not assumed }\end{array}$ & & & -5.493 & 222.536 & .000 & -22.13000 & 4.02866 & -30.06921 & -14.19079 \\
\hline
\end{tabular}

Levene test describes unequal variance as per above table ( $\mathrm{p}$ value is less than 0.05 ). In the above table the $t$ value is 5.493 and $p$ value is less than 0.05 which indicates the rejection of null hypothesis. So the difference between two averages price index can be concluded.

$\mathrm{Ho}_{\mathrm{b}}$ : There is no significant difference between average WPI and average price index of Petrol.

\begin{tabular}{|c|c|c|c|c|c|c|c|c|c|c|}
\hline \multicolumn{11}{|c|}{ Independent Samples Test } \\
\hline & & \multicolumn{2}{|c|}{$\begin{array}{c}\text { Levene's Test for } \\
\text { Equality of Variances }\end{array}$} & \multicolumn{7}{|c|}{ t-test for Equality of Means } \\
\hline & & \multirow[t]{2}{*}{$\mathrm{F}$} & \multirow[t]{2}{*}{ Sig. } & \multirow[t]{2}{*}{$\mathrm{t}$} & \multirow[t]{2}{*}{ df } & \multirow[t]{2}{*}{$\begin{array}{l}\text { Sig. (2- } \\
\text { tailed) }\end{array}$} & \multirow[t]{2}{*}{$\begin{array}{c}\text { Mean } \\
\text { Difference }\end{array}$} & \multirow[t]{2}{*}{$\begin{array}{l}\text { Std. Error } \\
\text { Difference }\end{array}$} & \multicolumn{2}{|c|}{$\begin{array}{l}95 \% \text { Confidence } \\
\text { Interval of the } \\
\text { Difference }\end{array}$} \\
\hline & & & & & & & & & Lower & Upper \\
\hline \multirow{2}{*}{ PI_INDEX } & $\begin{array}{l}\text { Equal variances } \\
\text { assumed }\end{array}$ & 10.606 & .001 & -1.493 & 238 & .137 & -5.85800 & 3.92482 & -13.58983 & 1.87383 \\
\hline & $\begin{array}{l}\text { Equal variances } \\
\text { not assumed }\end{array}$ & & & -1.493 & 226.616 & .137 & -5.85800 & 3.92482 & -13.59182 & 1.87582 \\
\hline
\end{tabular}

Again Levene test describes unequal variance as per above table ( $p$ value is less than 0.05$)$. In the above table the $t$ value is -1.493 and $\mathrm{p}$ value is more than 0.05 which indicates that null hypothesis is accepted. So there is no difference between two averages price index. 
$\mathrm{Ho}_{\mathrm{c}}$ : There is no significant difference between average WPI and average price index of electricity.

\begin{tabular}{|c|c|c|c|c|c|c|c|c|c|c|}
\hline \multicolumn{11}{|c|}{ Independent Samples Test } \\
\hline & & \multicolumn{2}{|c|}{$\begin{array}{c}\text { Levene's Test for Equality } \\
\text { of Variances }\end{array}$} & \multicolumn{7}{|c|}{ t-test for Equality of Means } \\
\hline & & \multirow[t]{2}{*}{$\mathrm{F}$} & \multirow[t]{2}{*}{ Sig. } & \multirow[t]{2}{*}{$\mathrm{t}$} & \multirow[t]{2}{*}{$\mathrm{df}$} & \multirow[t]{2}{*}{$\begin{array}{l}\text { Sig. (2- } \\
\text { tailed) }\end{array}$} & \multirow[t]{2}{*}{$\begin{array}{c}\text { Mean } \\
\text { Difference }\end{array}$} & \multirow[t]{2}{*}{$\begin{array}{l}\text { Std. Error } \\
\text { Difference }\end{array}$} & \multicolumn{2}{|c|}{$\begin{array}{l}95 \% \text { Confidence Interval } \\
\text { of the Difference }\end{array}$} \\
\hline & & & & & & & & & Lower & Upper \\
\hline \multirow{2}{*}{ PI_INDEX } & $\begin{array}{l}\text { Equal variances } \\
\text { assumed }\end{array}$ & 22.151 & .000 & 7.345 & 238 & .000 & 22.55250 & 3.07064 & 16.50340 & 28.60160 \\
\hline & $\begin{array}{l}\text { Equal variances not } \\
\text { assumed }\end{array}$ & & & 7.345 & 222.099 & .000 & 22.55250 & 3.07064 & 16.50118 & 28.60382 \\
\hline
\end{tabular}

Levene test describes unequal variance as per above table ( $p$ value is less than 0.05). In the above table the $t$ value is 7.345 and $\mathrm{p}$ value is less than 0.05 which indicates that null hypothesis is rejected. So there is a significant difference between two averages price index.

$\mathrm{Ho}_{\mathrm{d}}$ : There is no significant difference between average WPI and average price index of MILK.

\begin{tabular}{|c|c|c|c|c|c|c|c|c|c|c|}
\hline \multicolumn{11}{|c|}{ Independent Samples Test } \\
\hline & & \multicolumn{2}{|c|}{$\begin{array}{c}\text { Levene's Test for Equality of } \\
\text { Variances }\end{array}$} & \multicolumn{7}{|c|}{ t-test for Equality of Means } \\
\hline & & \multirow[t]{2}{*}{$\mathrm{F}$} & \multirow[t]{2}{*}{ Sig. } & \multirow[t]{2}{*}{$\mathrm{t}$} & \multirow[t]{2}{*}{$\mathrm{df}$} & \multirow[t]{2}{*}{$\begin{array}{l}\text { Sig. (2- } \\
\text { tailed) }\end{array}$} & \multirow[t]{2}{*}{$\begin{array}{c}\text { Mean } \\
\text { Difference }\end{array}$} & \multirow[t]{2}{*}{$\begin{array}{l}\text { Std. Error } \\
\text { Difference }\end{array}$} & \multicolumn{2}{|c|}{$\begin{array}{l}95 \% \text { Confidence } \\
\text { Interval of the } \\
\text { Difference }\end{array}$} \\
\hline & & & & & & & & & Lower & Upper \\
\hline \multirow{2}{*}{ PI_INDEX } & $\begin{array}{l}\text { Equal variances } \\
\text { assumed }\end{array}$ & 95.528 & .000 & -4.303 & 238 & .000 & -22.02333 & 5.11801 & 32.10571 & 11.94096 \\
\hline & $\begin{array}{l}\text { Equal variances not } \\
\text { assumed }\end{array}$ & & & -4.303 & 183.694 & .000 & -22.02333 & 5.11801 & 32.12096 & 11.92570 \\
\hline
\end{tabular}

Levene test describes unequal variance as per above table ( $\mathrm{p}$ value is less than 0.05 ). In the above table the $\mathrm{t}$ value is 4.303 and $p$ value is less than 0.05 which indicates that null hypothesis is rejected. So there is a significant difference between two averages price index.

$\mathrm{Ho}_{\mathrm{e}}$ : There is no significant difference between average WPI and average price index of LPG.

\begin{tabular}{|c|c|c|c|c|c|c|c|c|c|c|}
\hline \multicolumn{11}{|c|}{ Independent Samples Test } \\
\hline & & \multicolumn{2}{|c|}{$\begin{array}{c}\text { Levene's Test for Equality } \\
\text { of Variances }\end{array}$} & \multicolumn{7}{|c|}{ t-test for Equality of Means } \\
\hline & & \multirow[t]{2}{*}{$\mathrm{F}$} & \multirow[t]{2}{*}{ Sig. } & \multirow[t]{2}{*}{$\mathrm{t}$} & \multirow[t]{2}{*}{$\mathrm{df}$} & \multirow[t]{2}{*}{$\begin{array}{l}\text { Sig. (2- } \\
\text { tailed) }\end{array}$} & \multirow[t]{2}{*}{$\begin{array}{c}\text { Mean } \\
\text { Difference }\end{array}$} & \multirow[t]{2}{*}{$\begin{array}{l}\text { Std. Error } \\
\text { Difference }\end{array}$} & \multicolumn{2}{|c|}{$\begin{array}{l}\text { 95\% Confidence Interval } \\
\text { of the Difference }\end{array}$} \\
\hline & & & & & & & & & Lower & Upper \\
\hline \multirow{2}{*}{ PI_INDEX } & $\begin{array}{l}\text { Equal variances } \\
\text { assumed }\end{array}$ & .376 & .540 & 3.045 & 238 & .003 & 10.31750 & 3.38803 & 3.64314 & 16.99186 \\
\hline & $\begin{array}{l}\text { Equal variances not } \\
\text { assumed }\end{array}$ & & & 3.045 & 237.597 & .003 & 10.31750 & 3.38803 & 3.64308 & 16.99192 \\
\hline
\end{tabular}




\section{Independent Samples Test}

Levene test describes equal variance as per above table ( $p$ value is more than 0.05 ). In the above table the $t$ value is 3.045 and $p$ value is less than 0.05 which indicates that null hypothesis is rejected. So there is a significant difference between two averages price index.

\section{CONCLUSION}

The above study reveals that WPI is not a true interpretator of Inflation in the economy. WPI index has many such commodities which are not consumed by common or middle class people and these types of commodities dilute the inflation rate. For example the inflation in case of bicycle is taken while calculating WPI but in actual practice a lower income group people will consume the bicycle and that too will be bought once or twice in their lives. So to represent the true picture of inflation in India there should be a fair and precise index. Right measure of inflation will be beneficial for the growth of the country.

\section{REFERENCES AND BIBLIOGRAPHY}

1. Aviral Kumar Tiwari, (2012) "Causality between wholesale price and consumer price indices in India: An empirical investigation in the frequency domain", Indian Growth and Development Review, Vol. 5 Iss: 2, pp.151 172

2. Hall, Robert E.; Taylor, John B. (1993). Macroeconomics. New York: W.W. Norton. p. 637. ISBN 0-393-96307-1

3. Patnaik ILa, Shah Ajay and Veronese Giovanni (2011).”How to Measure Inflation In India?”. . JEL classification: E52; E58.

4. Pawar Ashok Shankarrao and Naik Vasantrao (2013). "An Analytic study of Inflation in India". The global Journals, Volume : 3, Issue : 9

5. Rao Nagabhushana and Reddy Chenchu (2013).” A Study on Inflation in India". International Research Journal of Social Sciences ISSN 23193565 Vol. 2(12), 51-55

6. Www.eaindustry.nic.in/

7. Https://data.gov.in/keywords/wholesale-priceindex
8. Www.indiastat.com/economy/8/ wholesalepriceindex/14428/.../stats.aspx

9. Http://www.thehindu.com/business/Economy 